\title{
A CSALÁD SZEREPE A MUNKAVÁLLALÁSBAN EGYETEMISTÁK KÖRÉBEN
}

\section{Szerzők:}

Balogh Vivien

Debreceni Egyetem (Magyarország)

Nagy Nikoletta

Debreceni Egyetem (Magyarország)

\author{
Lektorok: \\ Kovács Karolina Eszter( $(\mathrm{PhD})$ \\ Debreceni Egyetem (Magyarország) \\ Ceglédi Tímea (PhD) \\ Debreceni Egyetem (Magyarország)
}

\author{
Solymosi Petra Emma \\ Debreceni Egyetem (Magyarország)
Első szerző e-mail címe:
vivike0223@gmail.com

(a)

Balogh Vivien, Nagy Nikoletta, Solymosi Petra Emma (2021). A család szerepe a munkavállalásban
egyetemisták körében. Különleges Bánásmód, 7. (2). 7-19. DOI 10.18458/KB.2021.2.7 
egyetemi tanulmányok melletti munkavállalás arányát, amelynek hátterében elsősorban a család financiális állapota áll.

Kulcsszavak: családszerkezet, munkavállalás, kulturális tőke

Diszciplina: pl. pedagógia, pszichológia

\section{Abstract \\ THE ROLE OF THE FAMILY IN EMPLOYMENT AMONG UNDERGRADUATES}

The role of the family as the arena for primary socialization is significant throughout our lives. The cultural capital, parental role models, and relationship with siblings all have a tremendous impact on academic and non-academic achievement, social networking, intra- and intergenerational embeddedness, and employment during studies. However, a change in family structure can negatively affect a child's development, decrease his or her academic and non-academic achievement (Engler, 2016), and also causes a higher prevalence of health risk behaviours (Kovács and Nagy, 2017). In addition, due to the lower level of financial capital provided by the family, young people who have grown up in a non-intact family structure are often forced to work during their university or even high school studies to ensure their selfpreservation. In our research, we examined the attitudes of the students studying at the University of Debrecen towards family and work in the light of the family structure, covering childhood storytelling experiences (BEST 2020). In addition to demographic issues, changes in family structure, childhood storytelling habits, and work-related attitudes were examined ( $\mathrm{N}=159) .25 .6 \%$ of the students' parents are divorced, $24.3 \%$ grew up with their mother. $86.5 \%$ of the parents read tales in childhood, mostly $(75 \%)$ every day, typically mothers. No significant difference could have been detected in childhood storytelling experiences based on family structure $(\mathrm{p}=0.322)$. Although the ratio of employment is higher among children of divorced parents, a significant difference is found at the beginning of employment. Based on the results, parents try to support university studies at least partly, but they are unlikely able to provide other resources that could force students to work. Based on our results, it can be stated that the role of the family in the early employment of young people is also significant, and the change in the family structure increases the proportion of employment besides university studies, which is mainly due to the family's financial situation.

Keywords: family structure, employment, cultural capital

Disciplines: pedagogy, psychology

\section{A család szerepe}

A család az elsődleges szocializációs közeg, fogalma összekapcsolódott a házassággal és a gyermekneveléssel is. Bizonyos felmérések arra utalnak, hogy a családnak és a házasságnak általánosan pozitív a megitélése napjainkban (Engler, 2018). Ugyanakkor napjainkban egyre gyakrabban kell szembesülnünk a családszerkezet megváltozásával, az utóbbi évtizedekben ugyanis átalakult a család helye és szerepe a modern társadalmakban. A házasságon kívüli együttélés egyre nagyobb teret hódít, és ezzel párhuzamosan megnőtt a házasságon kívüli születések aránya, miközben a válási hajlandóság is egyre magasabb (Földházi, 2008; Kapitány és Murinkó, 2020). Az 1960-as években más, a monogám családot tagadó együttélési formák (kommuna, csoportházasság) is megjelentek. Mozgalmak indultak az azonos nemú személyek közötti élettársi, esetleg 
házassági kapcsolatok teljes egyenjogúsításáért. Lényeges változás a szándékos gyermektelenség is, ami a nôi egyenjogúságért folytatott mozgalmak újraéledésével függenek össze (Püski, 2000; Spéder, 2019). A szignifikáns társadalmi és az iskolarendszert is érintő változások ellenére mégis elmondható a hazai és nemzetközi kutatások alapján, hogy a családi háttér jelentősen hat a tanulmányi-munkavállalói, valamint a magánéleti pályafutásra egyaránt (Engler, 2020; Ceglédi, 2017; 2018).

A családi egység felbomlása gyermekszemmel igen megterhelő élmény, mivel ekkor megrendülhet az addigi biztonságot nyújtó környezetbe vetett bizalom. 1987-ben volt a legmagasabb, 2,8 az ezer lakosra jutó válások száma, majd az ezt követô évtizedekben 2,0-2,5 között ingadozott. 2017-ben csökkent először 2 ezrelék alá a mutató értéke (KSH, 2019).

A szülők „elérhetőségének” szerepére is számos szakirodalom rámutatott a tanulmá-nyi pályafutás kapcsán (Pusztai, 2009; Coleman, 1998; Engler, 2016; Ceglédi, 2012; 2020). A stabil családi háttér a legmegfelelőbb a gyermekek fizikai, pszichikai és szellemi fejlődésének (Pusztai és Engler, 2020; Kovács, 2020; Engler, 2016; Kozma, 1975). Ahol hiányzik az egyik szülő, ott bizonyta-lanabb a szülooi kontroll és sérülékenyebb a norma-biztonság (Coleman, 1998; Pusztai, 2009). A családban bekövetkező strukturális válság a gyermekek korai munkavállalását eredményezheti, valamint a tanulmányi eredményesség és a mentális egészség romlásához vezethet (Kocsis, 2019; Kovács és tsai, 2018). Korábbi kutatások rávilágítottak továbbá a családszerkezet megváltozásának mentális egészségére gyakorolt negatív hatásaira is (Kovács és Nagy, 2017). A segító szakemberek gyakrabban találkoznak elvált szülők gyermekeivel, míg az intakt családban élő gyermekek körében ritkábban van szükség hasonló problémák miatt szakember bevonására (Bognár, 1986).

A válás elôtti időszakban néha éveken keresztül jelen van a családi életben a megromlott szülő- kapcsolat, a kommunikáció hiánya, a munkahely elvesztése (hibáztatás, szemrehányás, rágalmazás, anyagi biztonság hiánya). Az eredménytelen konfliktuskezelés, kibékíthetetlen ellentét miatt a problémából való kihátrálás jellemző (munkába, alkoholba, házasságon kívüli kapcsolatokba, menekvésbe stb.).

Ezek a folyamatok mentálisan romboló hatásúak és rossz mintát nyújtanak a gyerekeknek. Kihatással lehetnek a későbbi konfliktuskezelési adottságaikra, párkapcsolataikra, késóbbi családi állapotukra és a gyermekvállalásra, gyermeknevelésre egyaránt (Visontai-Szabó, 2018). Az állandó feszültség és veszekedés megmérgezi a légkört, elvész a biztonságérzet, a meghittség, és teljesen a bizalmatlanság és csalódottság érzése fog eluralkodni. A válás szerepe a családi viszonyok átrende-zésében fokozatosan nőtt az elmúlt évtizedekben. Elterjednek az egyszülős családok, az egyedül élők aránya növekszik, megjelennek az új családi formák is (pl. élettársi kapcsolatok) (Püski, 2000; Visontai-Szabó, 2018).

Ugyanakkor a válás megfelelő módja tompíthatja ezt a hatást (pl. szoros szülő-gyerek kapcsolat, testvérkapcsolatok, konfliktusok hatékony kezelése stb.). A családi kapcsolatokra következtethetünk például a meseolvasásból is. Az életbe való beilleszkedés egyik elengedhetetlen eleme, hogy fel tudjuk ismerni saját és mások érzelmeit, vagyis ha fejlett az érzelmi intelligenciánk. A mese egy olyan eszköz, amely ennek a fejlesztésére szolgál. A gyerekek számára egy olyan lelki táplálék, amely érzelmi biztonságot is ad (Kádár, 2013). Kutatásunkban a meseolvasási szokások bemutatása által a család belső múködésébe nyújtunk betekintést az elvált és nem elvált szülők gyermekei körében.

\section{A munkavállalás}

Az eddigi ismert adatok alapján kijelenthető, hogy egyre több fiatal vállal munkát iskolai tanulmányai mellett. Ezt bizonyítja a Magyar Ifjúság 2016-ban elkészített kutatása is, ahol a meg- 
kérdezett fiatalok 54 százaléka jelentette ki, hogy dolgozott már élete során, és ez az arány a négy évvel korábbi felvételben tapasztalt 40 százalékhoz képest erôs növekedést mutatott (Bauer et al., 2016).

Továbbá az is látható, hogy azok, akik tanulmányaik mellett rendszeresen dolgoztak, átlagosan hamarabb képesek elhelyezkedni a munkaerőpiacon azokkal összevetve, akik soha nem dolgoztak tanulmányaik mellett (Bauer és Szabó, 2009; Hvozdetska és tsai, 2020). Az Aktív Fiatalok 2013 kutatás eredményei alapján a hallgatók 19\%-a dolgozott a megkérdezéskor rendszeresen, 20\%-uk alkalmanként, és 60\%-ukról volt elmondható, hogy nem végzett keresôtevékenységet (Szőcs, 2013). Egy 2003-as TÁRKI kutatás alapján a hallgatók bő egynegyede (26\%) dolgozik alkalmanként, 15\%-uk gyakran, 18\%-uk pedig rendszeresen (idézi Gáti és Róbert, 2013). A 2015-ös HÖOK Mentorprogram kutatás szerint a mentoráltak 35,8\%-a dolgozott állandó vagy alkalmi jelleggel (Veroszta, 2016). Ráadásul a végzett munkával való elégedettség nem csupán a munka melletti elköteleződést növeli, hanem az egészségi állapotra is kedvező hatással bír, hiszen növeli a boldogságérzetet, a jóllét szintjét és az önértékelést is (Satuf és tsai, 2016).

Ezek az adatok azt bizonyítják, hogy nemcsak egyre népszerúbb a tanulmányok mellett folytatott munkavállalás, de ennek számos pozitív következménye is van. Ráadásul, ha a személy a szakmájához illeszkedő munkát végez hallgatókorában, az növeli a felsőfokú tanulmányok folytatásának valószínűségét, az elhelyezkedési esélyeket, a munka szakhoz illeszkedését és csökkenti az elhelyezkedési idôt a diplomaszerzés után is (Veroszta 2014, Sági, 2013; Gáti és Róbert, 2013). Emellett a társadalmi hovatatozás, ha nem is mindig közvetlen módon, de befolyásolja a hallgatói munkavégzés szakhoz való illeszkedését (Nyüsti és Ceglédi, 2010; Szőcs, 2013, 2014; Gáti és Róbert, 2013, Markos, 2020; Ceglédi, 2018), s ennek az illeszkedésnek a társadalmi meghatározottsága nem írható felül az eredményességgel sem (Ceglédi, 2018). A munka során tapasztalatokat szerzünk, fejlődünk, kapcsolatokat építünk ki, megtanulunk önállóan és csapatban is dolgozni, valamint a munkatapasztalattal rendelkezők kelendőbbek a munkaerőpiacon (OECD, 2015; Szőcs, 2013).

Ám e pozitív dolgok mellett megjelennek sajnos negatív tapasztalatok is. Ilyen a lemorzsolódás, amire a munkavállalás kihat. Hazánkban 2018-ban az alapképzésben felvételt nyert egyetemisták 40 százaléka, míg a mesterképzésben részt vevő hallgatók 20 százaléka nem szerez végzettséget. Csók és munkatársai (2019) kvalitatív kutatásukban a hallgatói lemorzsolódás különböző szegmenseinek megjelenését vizsgálták, amely alapján a családi háttér, az esetleges korábbi tanulmányok, a pályaválasztás, a tanulás melletti munkavállalás, a társas kapcsolatok, valamint az egészségmagatartás egyes komponenseit emelték ki.. Emellett Kocsis és Pusztai (2020), valamint Pusztai és Szigeti (2019) is rámutat arra, hogy gyakran az iskola melletti munkavállalás következményeként lemorzsolódás jelenik meg. A tanuló motiváltsága, érdeklődési köre és alkalmazkodási képessége további befolyásoló faktorként jelenhet meg, ahogyan a család anyagi helyzete (Pusztai és Kocsis, 2019) vagy éppen annak strukturális állapota is. Minél alacsonyabb fokon tanul és mellette dolgozik is a tanuló, annál inkább valószínú, hogy a család rossz anyagi helyzete áll a háttérben, s nem egyfajta önállósodási szándék (Szűgyi, 2019). Kutatásunk kérdése, hogy melyik irányba billen a mérleg: a munkavállalás pozitív vagy negatív irányban befolyásolja a tanulmányokat?

\section{A családszerkezet megváltozása és a fiatal munkavállalása}

A családszerkezet hatása jelentős lehet az egyetemi tanulmányok melletti munkavállalásra. Feltehető, hogy akik egy kétszülős háztartásban nőttek fel, olyan szülókkel, akik tartósan dolgoztak életük 
során, nagyobb eséllyel vetik bele magukat a munka világába is, mivel a szüleik példáját követik. Azonban olyan eset is előfordulhat, ahol ennek az ellentétével találkozunk, vagyis a gyermek a szülei biztos családi helyzete és financiális állapota miatt úgy érzi, nem szorul rá arra, hogy munkát keressen, mert az neki biztosítva lesz (Paksi és tsai, 2020). Az egyetemisták átlagos bevételi forrása nagyban összeköthető a szülók iskolázottságával is. Egyes kutatások szerint, megfigyelhető hogy azok a fiatalok, akiknek szüleik diplomával rendelkeznek, nagyobb valószínúséggel alapozhatják a megélhetésüket a családi keresetre, tehát kevesebb eséllyel kezdenek bele egy munkába. Ezzel ellentétben azok a fiatalok, akiknek szüleik nem rendelkeznek diplomával, nem tudnak minden esetben a családi bevételre támaszkodni, és nagyobb eséllyel kezdenek munkába egyetemista éveik alatt (Garai és Kiss, 2014).

Jelen kutatás arra keresi a választ, hogy milyen a család szerepe a fiatalok korai munkavállalásában, a család szerkezetében beállt változás pedig hogyan befolyásolja az egyetemi tanulmányok melletti munkavégzést, amelynek hátterében elsősorban a család financiális állapota áll. Emellett azt vizsgáljuk, hogy a mai fiatalok, akik egyetemi tanulmányaik mellett kezdenek el dolgozni, nagyobb eséllyel rendelkeznek-e elvált szülőkkel, vagy gyenge családi körülményekkel, mint ha ez nem így lenne. Elemezzük továbbá azt, hogy a munkavállalással kapcsolatos tényezők milyen negatív és pozitív hatást gyakorolhatnak az iskolai teljesítményre.

\section{Módszer}

Kutatásunkban a Debreceni Egyetem hallgatóinak családdal és munkával kapcsolatos attitűdjeit vizsgáltuk a családszerkezet függvényében, kitérve a gyermekkori meseolvasási tapasztalatokra. A BEST 2020 kutatás során a demográfiai kérdések mellett a család szerkezetében történt változások, a gyermekkori meseolvasási szokások, valamint a munkavállalással kapcsolatos attitűdök vizsgálatára került sor $(\mathrm{N}=159)$. Mivel hallgatókat vizsgáltunk, ezáltal sikeres életpályán lévőkből merítettünk, így ők lehetnek például a válással sikeresen megküzdők. Eredményeink ennek tükrében értelmezendők.

\section{Minta}

A mintavétel - a lehetőségekből adódóan - nem valószínúségi, a minta nem reprezentatív semmilyen előzetes ismérv alapján. Kutatásunk eredményeinek általánosíthatósága ezáltal korlátozott. $\mathrm{Az}$ adatfelvétel által ugyanakkor betekintést nyerhetünk egy fontos téma mögötteseibe.

A kérdő́ív nyitott válaszadói körrel rendelkezett, a célcsoportnak megfelelően a válaszadók $(\mathrm{N}=200)$ többsége egyetemi hallgatókból állt, a nem egyetemi hallgatókat leválogattuk a mintából (így az elemzett mintanagyság $\mathrm{N}=157$ ). A válaszadók 89,7 \%-a nő, 10,3\%-a férfi nemú volt. Ezalapján elmondható, hogy a kitöltők között felülreprezentáltak a nők. A kitöltők átlagéletkora 22,87 év $(\mathrm{sd}=6,59)$.

A kérdőívben vegyesen szerepteltek nyitott és zárt kérdések, tehát az alany a megadott válaszlehetőségek alapján és saját szavaival is megoszthatta velünk véleményét. A kutatás tanulmányozta a szülők iskolai végzettségét is, mivel ez nagyban befolyásolhatja a gyermekek oktatási eredményességét (Kiss, 2014). A kitöltők többségének édesanyja $(38,8 \%)$ szakiskolai, és $(29,4 \%)$ középiskolai végzettséget szerzett; édesapja $(58,1 \%)$ szintén szakiskolai, és $(23,3 \%)$ középiskolai végzettséggel rendelkeznek. A válaszadók döntő többségének, 80,6\%-nak van egy vagy több testvére, $52 \%$ számolt be egy testvérről.

A kutatás során a szakirodalmi előzmények alapján a következő hipotéziseket állítottuk fel:

H1: Az elvált szülőkel rendelkező kitöltők körében a gyermekkori meseolvasási gyakoriság jelen- 
tősen alacsonyabb az elvált szülőkkel nem rendelkező kitöltőkkkel összevetve.

H2:Az elvált szülőkkel rendelkező kitöltők tanulmányi eredménye rosszabb az elvált szülők-kel nem rendelkező kitöltőkkel összevetve.

H3: Azok a kitöltők, akik egyetemi tanulmányaik mellett dolgoznak, rosszabb tanulmányi eredményességgel jellemezhetők, mint nem dolgozó kortársaik.

H4:Azok a kitöltők, akiknek szülei elváltak, szignifikánsan hamarabb lépnek be a munkaerőpiacra az elvált szülőkkel nem rendelkező kitöltőkkel összevetve.

H5:Az elvált szülőkel rendelkező kitöltőket kevésbé tudják anyagilag támogatni szüleik, mint az elvált szülőkkel nem rendelkező kitöltőket.

H6:Azok körében gyakoribb a hallgatói munkavégzés, akiknek tanulmányait kevésbé támogatják a szüleik.

\section{Eszközök}

Jelen kutatás kvantitatív, online kérdőíves formában valósult meg. A kutatás függó változói a családszerkezet, a munkavállalás, valamint a tanulmányi eredményesség volt, független változóink pedig a nem, az életkor, az iskolai végzettség, a lakóhely és a családszerkezet voltak. A kutatás elsősorban a gyerekekre gyakorolt hatást vizsgálja, a kérdőívben azonban a már felnőtt korosztály szemszögéból kaptunk retrospektív jellegú adatokat, ami jól tükrözi a hosszú távú hatásokat is.

A kérdőívben a következő kérdéscsoportok vizsgálatára került sor

- szociodemográfiai kérdések,

- családszerkezetre és válásra vonatkozó kérdések,

- munkavállalásra irányuló kérdések,
- felsőoktatási tanulmányi eredményességre vonatkozó kérdések.

A kérdőívet online készítettük el google kérdőív formájában, amely különböző social media felületeken került megosztásra. A statisztikai elemzéshez az SPSS 22.0 for Windows statisztikai szoftvert használtuk. Az eloszlásbeli különbségek feltárásához khi-négyzet próbát, valamint Fisher-féle egzakt próbát alkalmaztunk, a csoportok összevetéséhez (folytonos változók esetén) az adatok nem normális eloszlására való tekintettel (Kolmogorov-Smirnov próba, $\mathrm{p}<0,05)$ Mann-Whitney próbát alkalmaztunk.

\section{Eredmények}

\section{A válás hatása}

A kutatás egyik célja fényt deríteni arra, hogy maga a válás hogyan hat az egyénre, milyen következményei és kihatásai lesznek a jövőre nézve. Felmerülhet az a kérdés, hogy a válás, mint megtörtént esemény okoz-e hosszútávú sebeket, vagy inkább a válás előtti időszak hagyhat-e mély nyomokat a gyermekben. A hallgatók 26,3\%-ának családjában történt válás, illetve további 4,2\% mondta azt, hogy nem váltak el, de különköltöztek szülei, amely alacsonyabb a hazai válási arányszámhoz képest (KSH, 2019). A kérdôívet kitöltő hallgatók körében tehát alulreprezentált ez a jelenség.

A kutatás fényt derített arra, hogy a vizsgált célcsoport átlagosan 10,6 éves korában élte át a válást. A válás okaként (1.ábra) a legmagasabb arányban a másik fél káros szenvedélye jelent meg (30,4\%), és csak-nem ugyanennyien jelölték a harmadik fél belépését (28,6\%). A kibékíthetetlen ellentét $\mathrm{kb}$. minden ha-todik esetben jelent meg válási okként, $\mathrm{s}$ a válaszok negyedének esetében valamilyen egyéb okot jelöl-tek (azt azonban nem kifejtve). 
1. ábra: A válás oka (\%) (A válás okáat megjelölök körében, Forrás: BEST 2020, N=57)

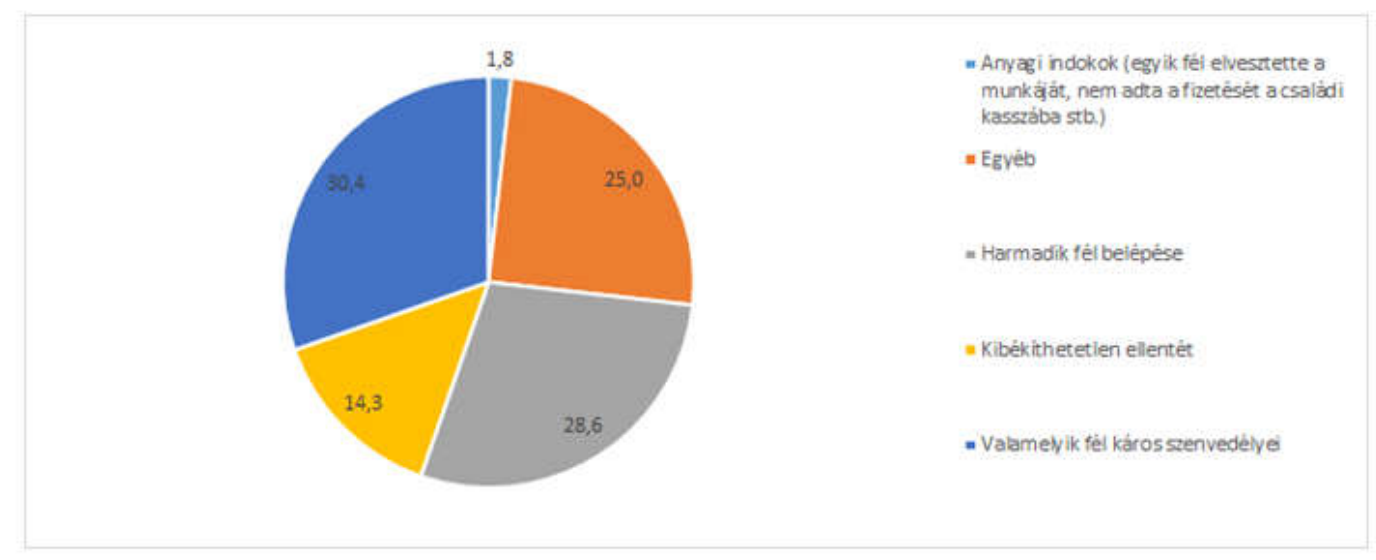

A kérdőív megkérdezte, hogy mennyire avatták be a kitöltőt, illetve a testvéreit a válás folyamatába. A válaszokból kiderült, hogy nagyrészben mindenról tudtak a gyermekek. Sokan érezték már, hogy nincs minden rendben. Érzékelték a veszekedéseket, konfliktuskezelési problémákat és az elhúzódó feszült légteret. Sokan fiatalon nem igazán tudtak mit kezdeni a helyzettel. Felnőve viszont már másképp tudták újraértékelni a megtörténteket és jobban megérteni az ok-okozati összefüggéseket is, hogy mi miért történt meg. A kérdőívben olyan kérdéseket tettünk fel a válaszadóknak, mint például: "Ki kezdeményezte a válást?”, "Mi volt a válás oka?", "Mennyire avatták be Önt, illetve testvéreit (ha van) a válás okaiba, részleteibe?, Tudott-e / Tudtak-e az eseményről kezdettől fogva, vagy csak a tényeket közölték a szülei Önnel / Önökkel? “.

A válás időszakban a válaszadók nagyrésze leginkább az édesanyára, a testvérekre és a nagyszülőkre tudott megfelelően támaszkodni.

Megvizsgáltuk azt is, milyen hatással bír a családszerkezet változása a gyermek- és felnőttkori meseolvasási szokásokra. Alapvetően a hallgatók 86,5\%-ának olvastak mesét gyermekkorában. Az elvált szülók gyermekeinek 90,2\%-a számolt be arról, hogy olvastak neki szülei mesét gyermekkorában, miközben ez az arány $85 \%$ a nem elvált családok gyermekei esetében. Mivel van olyan cella, ahol a mintaelemszám ötnél kisebb, Fisher-féle egzakt próbát alkalmaztunk, ez alapján pedig az eloszlásbeli különbség nem szignifikáns $(\mathrm{p}=0,592)$. A gyermekkorban szerzett kulturális tőke tekintetében a gyermekkori meseolvasási tapasztalatokban nem áll fenn jelentôs különbség a családszerkezet alapján. Első hipotézisünk, mely szerint a gyermekkorban tapasztalt szülő általi meseolvasás gyakorisága (mint a kulturális tôke átadásának egyik lehetősége) jelentősen alacsonyabb, nem igazolódott be.

A kitöltők egy ötfokú Likert-skálán értékelték a mesék nézését, a mesehallgatást és -olvasást mint kedvelt tevékenységet. Az eredmények alapján a hallgatók leginkább nézni szeretik a meséket $(4,75)$, majd hallgatni $(4,45)$, végül pedig olvasni $(3,89)$. Egyértelműen látszik továbbá, hogy a mesét, annak szerepét kiemelkedőnek tartják a hallgatók $(4,85)$.

Továbbá a kérdőív kitért a tanulmányi eredményességre is. Igazán meglepő és vegyes válaszok érkeztek arra a kérdésre, hogy a válás mennyire hatott ki az akkori tanulmányaira, amely kérdésre egy 1-től 5-ig terjedő Likert-skálához kellett viszo- 
nyítaniuk. 39\%-uk gondolta úgy, hogy semennyire sem hatott ki a tanulmányaira, minden a megszokott rutinban történt. Mindössze 8\%-uk választotta azt az opciót, hogy teljesen kihatott és hirtelen változás lépett be a tanulmányi eredményességük során. Ugyanakkor, ha a lelki oldalát nézzük, a válaszadók háromnegyedénél mélyen a válás folyamata viselte meg leginkább. Hosszabb távon gondolkozva, a jelenlegi tanulmányi eredményesség szempontjából az elvált szülók gyermekeinek súlyozott tanulmányi átlaga 3,11, az ép családok gyermekeinek esetében pedig 3,05. A különbség tehát minimális $(p=0,915)$. Második hipotézisünk tehát nem nyert megerősítést.

\section{Munkavállalás}

A hallgatók 36,8\%-a dolgozik egyetemi tanulmányai mellett. A munkakezdés átlagéletkora 18,15 év $(\mathrm{SD}=3,63)$. A munkavállalók közül a legnagyobb arányban az állandó munkát (37,1\%), valamint a diákmunkát $(37,1 \%)$ végzők vannak jelen a mintaban, amelytől jelentősen alacsonyabb a gyakornoki munkát végzők (12,9\%), a részmunkaidőben foglalkoztatottak $(8,1 \%)$, valamint az alkalmi munkavállalók $(4,8 \%)$ aránya. A munkavállalók többsége (30,4\%) 10-20 órát dolgozik egy héten. Öket követik a kevesebb mint 10 órát dolgozók (26,1\%), a 30-40 órát, valamint a több mint 40 órát dolgozók (17,4\%-17,4\%), majd a 20-30 órát dolgozók $(8,7 \%)$. Érdekes módon a munkavállalók tanulmányi eredményessége jobbnak mutatkozott azon társaikkal összevetve, akik nem dolgoznak, hiszen a munkavállaló súlyozott átlaga 3,42, míg a nem dolgozóké 3,08, amely nem jelentős különbség $(\mathrm{p}=0,932)$. Hipotézisünkre válaszolva megállapítható, hogy nem teljesítenek rosszabbul a tanulmányokban azok, akik dolgoznak, sőt, magasabb súlyozott átlagot látunk, bár a különbség statisztikailag nem mutatkozott szignifikánsnak. Harmadik hipotézisünk tehát nem igazolódott be.

\section{A válás és korai munkavállalás kölcsönha- tásai}

Az elvált családban felnőtt gyermekek 43,9\%-a dolgozik jelenleg, míg a nem elvált családok gyermekei esetében ez az arány 33,3\%. A khinégyzet próba eredményei alapján az eloszlásbeli különbség nem szignifikáns $(\mathrm{p}=0,246)$. A munkakezdet tekintetében azonban jelentős hatás tapasztalható a családban történt szerkezeti változás kapcsán. Az elvált családokban felnőtt hallgatók első munkahelyre történő felvételének életkora 17,15 év, míg az intakt családszerkezetben felnőttek esetében 18,7 év. A Mann-Whitney próba eredményei alapján a különbség szignifikáns $(\mathrm{p}=0,005)$. Az alábbi táblázat szemlélteti a százalékos megoszlásokat az egyes életkori csoportokban történő munkakezdethez hozzárendelve. Az elvált családból származó gyermekek 80\%-a már dolgozik a 1418 év közötti életkorban, míg ez az arány 52,2\% a nem elvált családból érkezők esetében. A Fisherféle egzakt próba eredményei szignifikáns eloszlásbeli különbségre mutatnak rá $(p=0,012)$. Negyedik hipotézisünk, mely szerint az elvált családból érkező fiatalok körében jelentősen hamarabb történik meg a munkaerôpiacra való belépés, beigazolódott.

1. táblázat: A munkakezdet alakulása a szülók válásának. függvényében (Forrás: BEST 2020, N=104 munkavállalók almintája)

\begin{tabular}{|c|c|c|c|c|c|}
\hline & \multicolumn{3}{|c|}{ Munkakezdet/év } \\
\hline & & & 14-18 & $19-22$ & $23-26$ \\
\hline \multirow{4}{*}{$\frac{\infty}{\sim \pi}$} & \multirow{2}{*}{ nem } & $\mathrm{N}$ & 36 & 27 & 6 \\
\hline & & Sor $\%$ & 52,2 & 39,1 & 8,7 \\
\hline & \multirow{2}{*}{ igen } & $\mathrm{N}$ & 28 & 5 & 2 \\
\hline & & Sor $\%$ & 80,0 & 14,3 & 5,7 \\
\hline
\end{tabular}

A válás nem függ össze szignifikánsan azzal, hogy a család támogatja-e anyagilag a tanulmányokat. 
Az elvált szülók gyermekeinek 53,7\%-a számolt be arról, hogy szülei teljeskörúen finanszírozzák az egyetemi tanulmányaikat, 29,7\%-ukat részben támogatják a szülők, 17,1\%-uk pedig nem kap támogatást. Az el nem vált családok gyermekei esetében a teljes mértékủ támogatás aránya 54,2\%, a részben történő támogatás $35,5 \%$, a teljes támogatás hiánya pedig 10,3\%. A khi-négyzet próba eredményei alapján nem áll fenn jelentős eloszlásbeli különbség $(\mathrm{p}=0,480)$. Ötödik hipotézisünk így nem igazolódott.

A munkavégzés és a szülők általi támogatás szerinti megoszlás azonban már szignifikáns eltéréseket mutat $(\mathrm{p}<0,001)$. Viszonylag kicsi azoknak az aránya, akiket a szülők egyáltalán nem tudnak támogatni (12,2\%), jól látható azonban, hogy ezen hallgatók nagy része, 83,3\%-uk dolgozik, amely azért lehet szerencsés, mert ezek a hallgatók ilyen módon biztos bevételi forrást keresnek (akár a diákhitel felvételének elkerülése céljából is). Akiket a szülők részben tudnak támogatni, azoknak 48\%-a dolgozik, míg azok közt a legalacsonyabb a dolgozók aránya $(18,9 \%)$, akiknek tanulmányait a szülők finanszírozni tudják. A munkavállalás tényleges oka tehát sokkal inkább a szülők által biztosított támogatás mértékében keresendő, amelyre természetesen hatással lehet a válás, de elsősorban nem az határozza meg. Hatodik hipotézisünk tehát beigazolódott.

Összességben elmondható, hogy azok a fiatalok, akik tanulmányaik mellett dolgoznak, bár nem rendelkeznek nagyobb eséllyel elvált szülőkkel, vélhetően a gyenge családi körülmények és korlátozott családi erőforrások okán gyakrabban dolgoznak, és jelentősen hamarabb lépnek be a munkaerőpiacra.

\section{Megvitatás}

A család szerepe a gyermek életében meghatározó, elsődleges nevelési színtérként számos mintát ad a gyermek életvitelére vonatkozóan is. A család szerkezetének megváltozása az alapvető személyiségformálódáson túl azonban közvetve vagy közvetlenül az egyes eredményességi dimenziókra is jelentôsen hathat, mint a tanulmányi eredményesség (Engler, 2018), az egészség mint nemtanulmányi eredményesség (Kovács és Nagy, 2017) vagy éppen a munkavállalás (Kocsis, 2019).

Kutatásunkban a válás és a munkavállalás összefüggéseit vizsgáltuk online kérdőíves módszerrel. A kitöltők 26,3\%-ának családjában történt válás, valamint 4,2\%-uk esetében különköltöztek a szülők. Ez komoly szerkezeti változást jelent valamennyi családtag részére, amely alapjaiban hat a családtagok mindennapjaira, életvitelére, eredményességük különböző dimenzióira. A válást átélők esetében a váláskori életkor 10,4 év. A hazai trend alapján 2017-ben 84 gyermek jutott 100 válásra, életkor tekintetében ez 20 fő 0 és 6 év közötti, valamint 64 fó 7 és 17 év közti gyermeket jelent (KSH, 2019). A válás folyamatáról többségében tudtak a gyermekek, a válaszok alapján látható, hogy sokszor már azelőtt érezték a válás fenyegetését, hogy a szülők erről tájékoztatták volna őket, hiszen érzékelték a család megváltozott múködésmódját. A válaszadók nagy része, leginkább az édesanyára, a testvérekre és a nagyszülőkre tudott megfelelően támaszkodni, amely megfelel a korábbi trendeknek. Bár a válások esetében gyakran tapasztalható, hogy kevesebb erőforrás jut a gyermekre, a gyermekkori meseolvasási tapasztalatokban nem áll fenn jelentős különbség a családszerkezet alapján, hiszen az eredmények alapján az elvált családok gyermekeinek esetében is kimagaslóan jelen volt a gyermekkori meseolvasás.

$\mathrm{A} z$, hogy a válás mint megtörtént esemény vagy inkább a válás előtti időszak hatása erősebb, további kutatások alapját képezi. Ez persze egyéni és esetfüggő: nem mindegy ugyanis, hogy mi vezet váláshoz. Ennek megfelelően, a gyermek vonatkozásában meghatározó tényező lehet az is, mikor történik a válás. Egy nagyobb gyermek valószínúleg könnyebben fel tudja dolgozni az eseményeket (bár a serdülőkor szenzitív, kritikus periódusa okán a 
serdülőkre is szignifikánsan hathat). Természetesen nincs két egyforma válás, hiszen minden esetben egyedi, eltérő személyek és személyiségek vesznek részt a folyamatban, s ennek hatása is eltérő a további szereplőkre, így a gyermekre is (VisontaiSzabó, 2018).

A kutatásban megvizsgáltuk, lehet-e a válásnak hatása a fiatalok munkavállalására. Alapvetően a hallgatók harmada dolgozik egyetemi tanulmányai mellett, a munkakezdés átlagéletkora belenyúlik a középiskolai tanulmányok életkorába. Legtöbbjük állandó munkával rendelkezik, 10-20 órás heti munkavégzés mellett. Az elvált szülók gyermekei nincsenek túlsúlyban a munkavégzés tekintetében, azonban körükben a munkaerôpiacra való belépés jellemzően hamarabb, átlagosan csaknem másfél évvel korábban megtörténik. Az elvált családban felnövők túlnyomó többsége már középiskolai tanulmányai mellett is vállal munkát, jelentősen magasabb arányban, mint az intakt családszerkezetben felnőtt kortársak. Ennek ellenére a válás maga nem jelenik meg szignifikánsan a tanulmányok anyagi támogatásában, mert a tanulmányok finanszírozásának megoszlásában nincs különbség a két hallgatócsoport közt. A válás nincs hatással arra, hogy a család támogatja-e anyagilag a hallgatót. A kutatásunkban megkérdezett hallgatók anyagi támogatottsága nem különbözött az elvált és a nem elvált családok között. További nyitott kérdés azonban, hogy mekkora ennek a támogatásnak a mértéke, és ezzel összefüggésben hogyan kényszerül munkavállalásra egy-egy hallgató.

A munkavégzés és a szülők általi támogatás szerinti megoszlás azonban már szignifikáns eltéréseket mutat. Az eredmények azt mutatják, hogy a szülők az egyetemi tanulmányokat igyekeznek legalább részben támogatni, egyéb erőforrásokat azonban feltehetően nem tudnak biztosítani, amely munkavállalásra késztetheti a tanulókat. A munkavállalás tényleges oka tehát sokkal inkább a szülők által biztosított támogatás mértékében keresendő, amelyre természetesen hatással lehet a válás, de elsősorban nem az határozza meg. Látható azonban, hogy nem minden hallgató lép be a munkaerőpiacra a szülói támogatás hiányában. Esetükben feltehetően a diákhitel mint támogatási opció merülhet fel, amely azonban további kutatási kérdéseket vet fel.

Eredményeink alapján megállapítható, hogy a család szerepe a fiatalok korai munkavállalásában is jelentôs, a család szerkezetében beállt változás pedig növeli az egyetemi tanulmányok melletti munkavállalás arányát, amelynek hátterében elsősorban a család financiális állapota áll. A továbbiakban érdemes megvizsgálni a támogatás mértékének szerepét, hiszen eredményeink arra utalnak, hogy a támogatás mértéke lehet a kulcs az adatok hátterében meghúzódó okok feltárásához.

\section{Korlátozások}

Kutatásunk egyik limitációja a kutatási adatbázis nagysága és összetétele. A jövőben érdemes a kérdésköröket nagyobb és valószínűségi mintavételi elven gyüjtött mintán is vizsgálni. A kutatás eredményei reprezentativitás hiányában nem általánosíthatóak a teljes egyetemi populációra. Továbbá jelen kutatásban egyéni, többnyire zárt kérdések megfogalmazására került sor, továbbá sztenderdizált kérdésblokkok alkalmazása nem volt jelen. További összefüggések feltárásához érdemes lesz a fent megfogalmazott kérdéseket és megállapításokat validált és sztenderdizált kérdőívekkel és kérdésblokkokkal kiegészíteni.

\section{Konklúziók}

Eredményeink alapján megállapítható, hogy a család szerepe a fiatalok korai munkavállalásában is jelentôs, a család szerkezetében beállt változás pedig növeli az egyetemi tanulmányok melletti munkavállalás arányát, amelynek hátterében elsősorban a család financiális állapota áll. Az eredmények alapján a családszerkezeti változás közvetve hat az anyagi támogatásra, mivel az elvált szülôk ugyanúgy 
próbálják támogatni gyermeküket tanulmányaik elvégzésében, sokkal inkább a mindennapokban nyújtott támogatás mértéke apadhat el, hiszen alapvetően az elvált családok esetében alacsonyabb financiális tőketendenciák mutathatóak ki. Kulturális és emocionális tőke szempontjából azonban jelen minta nem mutatott jelentôs különbséget a válás alapján, tehát a szülők a válás ténye ellenére is próbálják a lehetôségeikhez mérten fenntartani a szükséges emocionális és anyagi támogatást.

A továbbiakban érdemes megvizsgálni a támogatás mértékének szerepét, hiszen eredményeink arra utalnak, hogy a támogatás mértéke lehet a kulcs az adatok hátterében meghúzódó okok feltárásához. Ezért további kutatásainkban a diákhitel, mint lehetséges opció vizsgálatát tervezzük, valamint nagyobb hangsúlyt fektetünk az elvégzett munka mennyiségére és minőségére, a tanulmányok és munkavégzési átfedések szerepére, valamint a hallgatók jelenlegi családi/párkapcsolati státuszára és financiális helyzetére.

\section{IRODALOM}

Bauer B., Pillók P., Ruff T., Szabó A., Szanyi F. E., \& Székely L. (2016). Ezele a mai magyar fiatalok! A Magyar Ifjúság Kutatás 2016 első eredményei. Budapest. Új Nemzedék Központ.

Bauer B., \& Szabó A. (Eds., 2009). Ifjúság 2008 gyorsjelentés. Budapest: Szociálpolitikai és Munkaügyi Intézet.

Bognár G., \& Telkes J. (1986). Budapest: A válás lélektana. Budapest: Közgazdasági és Jogi Könyvkiadó.

Ceglédi T. (2012). Reziliens életutak, avagy a hátrányok ellenére sikeresen kibontakozó iskolai karrier. Szociológiai Szemle, 22(2), 85-110.

Ceglédi T. (2017). A karriernek alárendelt magánélet vagy a karrierhez nélkülözhetetlen magánélet? A társadalmi hátrányaik ellenére sikeres, reziliens hallgatók tervei. In Engler Á. (Ed.), Család és karrier. Egyetemi hallgatók jövötervei (pp. 62-86.). Debrecen: CHERD-Hungary.
Ceglédi T. (2018). Ugródesžkán Reziliencia és társadalmi egyenlótlenségek a felsöoktatásban. Debrecen: CHERD-H.

Ceglédi T. (2020). Mitől lendül az ugródeszka? A hátrányok ellenére sikeres, reziliens negyedikes diákokat segítő tényezők. Kapocs, 19(2), 65-80.

Coleman, J. S. (1998). A társadalmi tőke az emberi tőke termelésében. In Gy. Lengyel, Z. Szántó (Eds.), Tókefajták: A társadalmi és kulturális eróforrások szociologiája.Budapest: Aula. 11-44.

Csók C., Hrabéczy A.,Németh D. K. (2019). Focus on the dropout students' secondary school experience and career orientation. Hungarian Educational Research Journal, 9(4), 708-720.

Engler Á. (2016). A család támogató szerepe. Kapocs, 15(4), 21-27.

Engler Á. (2018). Család és karrier. Debrecen: CHERD-H.

Engler Á. (2020). A szülőket és a pedagógusokat segítő családpolitikai intézkedések hatása és igénye. Kopp Mária Intéret a Népesedésért és a Családokért (KINCS) szakmai folyóirata, 3(2), 81-90.

Földházi E. (2008). Az elsố házasságkötés után- $A$ párkapcsolatok dinamikája, egyszülös családok kialakulása és megszünése Magyarországon a 20. század második felében (doktori értekezés). Budapest: Corvinus Egyetem.

Gáti A., Róbert P. (2013). Munkavállalás a tanulás mellett: kényszerűség vagy befektetés? In $\mathrm{O}$. Garai, Zs. Veroszta (Eds.), Frissdiplomások 2011 Budapest: Educatio Társadalmi Szolgáltató Nonprofit Kft. 93-109.

Garai O., Kiss L. (2014). EUROSTUDENT V magyarországi eredmények. In L. Kiss László (Ed.), A felsöoktatás szociális dimenziója. Az EUROSTUDENT $V$ kutatás hazai eredményei. Budapest, Educatio Nonprofit Kft. 5-26.

Hvozdetska, B., Varha, N., Nikon, N., Kocsis, Zs., Kovacs, K. (2020). Migratory Moods and Temporary Employment of Students of Central and Eastern Europe. Italian Sociological Review, 10(2), 305-326. doi: 10.13136/isr.v10i2.342 
Kádár A. (2013). Mesepszichológia. Budapest: Kulcslyuk Kiadó.

Kapitány B., \& Murinkó L. (2020). Párkapcsolati változások, termékenységi trendek. In T. Kolosi, I. Szelényi, I. Gy. Tóth (Eds.), Társadalmi Riport 2020. Budapest: TÁRKI. 146-170.

Kocsis Zs. (2019). Középiskolai diákok munkához és továbbtanuláshoz füződő viszonya. Educatio, 28(1), 158-165.

Kocsis, Zs., Pusztai, G. (2020). Student Employment as a Possible Factor of Dropout. Acta Polytechnica Hungarica, 17(4), 183-199.

Kovács K. E. (2020). A társadalmi struktúra és az oktatás összefüggései a sportiskolák rendszerében. Opus et Educatio: Munka és Nevelés, 7(1), 47-54.

Kovács K. E., Nagy B. E. (2017). Kockázatvállaló magatartás a családszerkezet függvényében, valamint hatása a tanulmányi eredményességre. PedActa, 7(1), 39-46.

Kovács K. E., Pusztai G., Kovács K.,Nagy B. E. (2018). A felsőoktatási társas integráció és a hallgatói egészségmagatartás kapcsolata. Pedacta, 8(1), 41-50.

Kozma T. (1975). Hátrányos helyzet: Egy oktatásügyi probléma társadalmi vetületei. Budapest: Tankönyvkiadó.

KSH (2019). A válások demográfiai jellemzői. Statisztikai tükör, http://www.ksh.hu/docs/ hun/xftp/stattukor/valas17.pdf

Markos V. (2020). Úton a felelös állampolgári lét felé az iskolai közösségi szolgálat közvetlen és közvetett hatásai. Debrecen: CHERD-H.

Nyüsti Sz., Ceglédi T. (2010). A három versengó dimenzió - Kísérlet hallgatói típusok kialakítására a tanulás, a szabadidó és a munka dimenziója mentén. In T. Kozma, T. Ceglédi (Eds.), Régió és oktatás - A Partium esete (Régió és Oktatás sorozat VII. kötet) Debrecen, CHERD-H. 93101.

OECD (2015). Az OECD kilátások a készségek területén 2015.: Ifjúság, készségek és foglalkoztatha- tóság. Letöltve 2020. 12.20. http://www.oecd.org/edu/oecd-skills-outlook2015-9789264234178-en.htm

Paksi B., Széll K., Magyar É., Fehérvári A. (2020). A lemorzsolódás egyéni és kontextuális tényezôi. Iskolakultúra, 30(8), 62-81.

Pusztai G. (2009). Társadalmi tóke és az iskolai pályafutás. Budapest: Új Mandátum Kiadó.

Pusztai G., Engler Á. (2020). Értékteremtő gyermeknevelés a családban és az oktatásban. Kopp Mária Intézet a Népesedésért és a Családokért (KINCS) szakmai folyórata, 3(2), 3-10.

Pusztai, G., Kocsis, Zs. (2019). Combining and Balancing Work and Study on the Eastern Border of Europe. Social Sciences, 8(6), 193.

Pusztai, G., Szigeti, F. (2019). Lemorzsolódás és perzisztencia a felsőoktatásban. Felsőoktatási kutatások a lemorzsolódás témakörében. Új Pedagógiai Sžemle, 26(11-12), 171-174.

Püski L. (2000). Magyarország a XX. században I-II. kötet. Szekszárd: Babits Kiadó.

Satuf, Monteiro, S., Pereira, H., Esgalhado,G., Afonso, R. M., Loureiro, M. (2016). The protecttive effect of job satisfaction in health, happiness, well-being and self-esteem, International Journal of Occupational Safety and Ergonomics, 24(2), 181-189. doi: $\underline{10.1080 /}$ $\underline{10803548.2016 .1216365}$

Sági M. (2013). Pályakezdő diplomások munkába állási stratégiái. In O. Garai, Zs. Veroszta (Eds.), Frissdiplomások 2011 Budapest: Educatio Társadalmi Szolgáltató Nonprofit Kft. Felsôoktatási Osztály. 111-142.

Spéder Zs. (2019). A hazai termékenységi magatartás nemzetközi összehasonlításban. (akadémiai doktori). Budapest: KSH.

Szilágyi M. (2007). A mese szerepe a gyermeki személyiségfejlődésben. Könyv és nevelés, 2(3).

Szőcs A. (2013). Munkaviszony és viszony a munkához - hallgatók a Debreceni Egyetemen. In T. Darvai (Eds.), Felsöoktatás és munkaeröpiac. 
Eszményektól a kompetenciák felé. Szeged: Belvedere Meridionale. 87-124.

Szőcs A. (2014). Teher alatt nő a pálma: hallgatók munkához való viszonya a Debreceni Egyetemen. In H. Fényes, I. Szabó (Eds.), Campus-lét a Debreceni Egyetemen. Debrecen: Debreceni Egyetemi Kiadó. 159-182.

Szűgyi J. (2019). Munkavállalás tanulói jogviszonnyal. Opus et educatio, 6(1), 87-108.

Veroszta Zs. (2014). Kinek meddig tart a felsőoktatás?: A tanulmányok alatti munkavállalás továbbtanulási tervekre gyakorolt hatása. In L. Kiss (Ed.), A felsőoktatás szociális dimenziója: $A$ Eurostudent $V$ magyarországi eredményei. Buda- pest: Educatio Társadalmi Szolgáltató Nonprofit Kft. 53-67.

Veroszta Zs. (2016). A felsőoktatási továbbtanulási motivációk vizsgálata. In A. Derényi, J. Temesi (Eds.), A magyar felsöoktatás 1988 és 2014 között Budapest: Oktatás-kutató és Fejlesztő Intézet. 153-200.

Visontai-Szabó K. (2018). Lélektani folyamatok és ezek következményei a szülők kapcsolatának felbomlása során. Magyar rendészet, 18(3), 125138. 